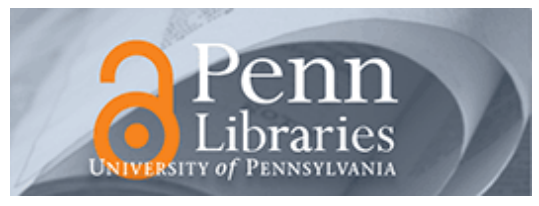

University of Pennsylvania

ScholarlyCommons

Finance Papers

Wharton Faculty Research

1996

\title{
What Can Explain the Apparent Lack of International Consumption Risk Sharing?
}

Karen K. Lewis

University of Pennsylvania

Follow this and additional works at: https://repository.upenn.edu/fnce_papers

Part of the Finance and Financial Management Commons

\section{Recommended Citation}

Lewis, K. K. (1996). What Can Explain the Apparent Lack of International Consumption Risk Sharing?.

Journal of Political Economy, 104 (2), 267-297. http://dx.doi.org/10.1086/262025

This paper is posted at ScholarlyCommons. https://repository.upenn.edu/fnce_papers/409

For more information, please contact repository@pobox.upenn.edu. 


\title{
What Can Explain the Apparent Lack of International Consumption Risk Sharing?
}

\begin{abstract}
Recent research in international business cycles finds that international consumption comovements do not match the risk-sharing predictions of standard complete markets models. In this paper, I ask whether two different types of explanations can help explain this result: (1) nonseparabilities between tradables and nontradable leisure or goods and (2) the effects of capital market restrictions on consumption risk sharing. I find that risk sharing cannot be resolved by either explanation alone. However, when I allow for both nonseparabilities and certain market restrictions, risk sharing among unrestricted countries cannot be rejected. This evidence suggests that a combination of these two effects may be necessary to explain consumption risk sharing across countries.
\end{abstract}

Disciplines

Finance and Financial Management 


\title{
What Can Explain the Apparent Lack of International Consumption Risk Sharing?
}

\section{Karen K. Lewis}

University of Pennylvania and National Bureau of Economic Research

\begin{abstract}
Recent research in international business cycles finds that international consumption comovements do not match the risk-sharing predictions of standard complete markets models. In this paper, I ask whether two different types of explanations can help explain this result: (1) nonseparabilities between tradables and nontradable leisure or goods and (2) the effects of capital market restrictions on consumption risk sharing. I find that risk sharing cannot be resolved by either explanation alone. However, when I allow for both nonseparabilities and certain market restrictions, risk sharing among unrestricted countries cannot be rejected. This evidence suggests that a combination of these two effects may be necessary to explain consumption risk sharing across countries.
\end{abstract}

International business cycle models with complete markets generally imply that consumption growth rates should be highly correlated with each other and more highly correlated than output growth rates. However, recent research has found the opposite result.' For this

I am grateful for useful discussions with and/or suggestions from Andy Atkeson, Dave Backus, Rich Clarida, Hal Cole, Domenico Cuoco, Urban Jermann, Maury Obstfeld, Andy Rose, José Scheinkman, Alan Stockman, Chris Telmer, Steve Zeldes, two anonymous referees, and seminar participants at the University of Pennsylvania, Columbia University, the London School of Economics, the Bank of Israel, and the National Bureau of Economic Research Summer Institute. I am also indebted to Alan Heston and Andy Rose for supplying data and to Alan Heston and Don Mathieson for useful conversations about the data. Any errors are mine alone.

${ }^{1}$ Leme (1984) and Scheinkman (1984) first described the implications of risk sharing for consumption growth rates across countries. Backus, Kehoe, and Kydland (1992) show that consumption correlations are too low to be explained by a model incorporating nonseparable leisure in the utility function. Devereux, Gregory, and Smith (1992) use a different model assuming separable leisure that generates consumption correlations more consistent with those in the data. 
reason, researchers have studied departures from standard assumptions in at least two general ways. First, if variables in the utility function that are internationally tradable are not separable from those that are nontradable, then the correlation of aggregate consumption growth rates need not be high. ${ }^{2}$ Second, international capital markets may not be complete. This second line of research has also shown that the asset market structure provides an important role in connecting business cycles across countries. ${ }^{3}$ In this paper I address the question, To what extent do nonseparabilities and incomplete markets explain the apparently low degree of risk sharing?

First, I ask whether the puzzle can be explained under complete markets by allowing for nonseparabilities in utility. While this possibility has been proposed by others, I use formal regression tests to provide confidence intervals on the magnitudes explained by nonseparabilities. These regressions show how much of the variation in cross-country consumption growth rates can be explained by potential nonseparabilities of tradables with leisure, nontraded goods, and durable goods. For these tests, I use two panel data sets: (1) aggregate consumption, output, and employment in 72 countries measured annually from 1950 to 1992; and (2) consumption disaggregated into groups of tradables and nontradables, and durables and nondurables, along with tradables output for 48 countries measured at 5-year intervals from 1970 to 1985 .

I find that nonseparabilities do not appear to explain the puzzle. Leisure explains less than 0.1 percent of the cross-country variation in consumption, although these results are based on unemployment data and should be viewed cautiously. ${ }^{4}$ More surprisingly, nondurable nontradable goods also explain a tiny fraction of the variation at 0.1 percent. Furthermore, when I account for these nonseparabilities, tradables consumption continues to be correlated with idiosyncratic variations in tradables output, in contrast to the predictions of complete markets models. While other studies combine durable and non-

2 Tesar (1993) makes this point. Stockman and Tesar (1995) simulate a two-country general equilibrium model with traded and nontraded goods. In earlier work, Stulz $(1981,1987)$ analyzes the effects of nontraded goods on international portfolio allocation. Backus et al. (1992) examine the effects of nonseparabilities with respect to nontradable labor. Scheinkman (1984) gives an example in which taste shocks play the same role as these nonseparabilities.

${ }^{3}$ For example, Baxter and Crucini (1995) and Conze, Lasry, and Scheinkman (1993) show that the transmission of shocks across countries depends on whether countries face restrictions in capital markets or not.

${ }^{4}$ Unemployment data are difficult to compare across countries because of differences in unemployment insurance and other labor market institutions (see Burdett and Wright 1989; Atkinson and Micklewright 1991). 
durable tradables in risk-sharing tests, I examine the importance of nonseparabilities between these two components. I find that nonseparabilities among all the components of consumption can account for up to about 13 percent of the cross-country variation in consumption, although risk sharing is still rejected. These results suggest that cornplete markets do not explain the international comovements of consumption, even after one allows for nonseparable utility.

Second, if countries are restricted from acquiring claims on foreign output, how would this affect the international comovements in consumption? To answer, I show that restrictions on ownership of foreign assets that take the form of taxes on repatriated earnings will generate a positive covariance between domestic consumption growth and domestic output. By using proxies for capital market restrictions, I then test whether countries with these restrictions have a higher covariation of domestic consumption growth with country-specific shocks than unrestricted countries do.

I consider two ways in which the capital market restrictions can resolve the risk-sharing puzzle. First, I ask whether the restrictions alone can explain the puzzle, ignoring nonseparabilities. While the covariation between idiosyncratic consumption and output is indeed significantly higher for restricted countries than for unrestricted countries, I find that risk sharing is rejected for both groups. Thus capital market restrictions do not explain the puzzle if nonseparabilities are ignored.

Second, I examine whether a combination of capital market restrictions and nonseparabilities can explain the puzzle. Strikingly, I find that both are important. For all measures of capital market restrictions that I consider, the relationship between components of utility for restricted countries is significantly different from that for unrestricted countries. For one measure, risk sharing in tradables among unrestricted countries is not rejected, even though risk sharing is rejected for restricted countries.

This evidence suggests that both nonseparabilities and capital market frictions are necessary to explain the behavior of international comovements in consumption. Nonseparabilities alone do not appear sufficient. Nor do capital market restrictions if nonseparabilities are ignored.

In this paper, I develop an approach that is different from the one typically used to examine the lack of international consumption risk sharing. ${ }^{5}$ Specifically, I use a regression approach that provides more

${ }^{3}$ Obstfeld (1989) and Canova and Ravn (1993) also take a regression-based approach but focus on time-series instead of cross-sectional information. 
evidence than can be found in the simple correlations across consumption growth rates used to match general equilibrium models in the existing literature. The regressions produce standard errors that show by how much risk sharing is rejected. The estimates also give the proportion of the unexplained variation in consumption across countries that can be explained by various nonseparabilities, providing an economic as well as statistical picture of the data. The regression approach also characterizes how any measurement error would have to behave to explain the apparent lack of consumption risk sharing.

The paper is structured as follows. Section I examines whether nonseparabilities can explain the lack of consumption comovements. Section II considers the effects of international market restrictions. Concluding remarks follow in Section III.

\section{Can Nonseparabilities under Complete Markets Explain It?}

I begin by asking to what extent nonseparabilities in utility between traded and nontraded leisure and goods can explain the lack of international risk sharing. To test for risk sharing, I shall use a modified version of the regression tests based on household data proposed by Cochrane (1991) and Mace (1991). The modification I introduce into these tests allows for nonseparabilities in utility.

\section{A. The Framework}

To illustrate the framework for these tests, I consider the social planner's problem of maximizing utility over $J$ countries with representative agents having utility functions $u\left(T^{j}\left(s^{t}\right), N^{j}\left(s^{t}\right), L^{j}\left(s^{t}\right)\right)$, where $j$ indexes the countries, $j=1, \ldots, J ; T^{j}, N^{j}$, and $L^{j}$ are, respectively, tradable consumption, nontradable consumption, and leisure in country $j$; and $s^{t}$ is the state of the economy at time $t$. Labor is immobile internationally and therefore functions as a nontraded good. Tradables and nontradables are both nondurable, and I begin by treating durables as separable in utility, although I consider the importance of durables below.

Given these assumptions, the social planner has the objective

$$
\max _{\left\{\left(s^{\prime}\right)\right\}_{j=1}^{J} \forall s^{\prime}} \sum_{j=1}^{J} \lambda^{j} \sum_{t=1}^{\infty} \rho^{t} \sum_{s^{t}} \pi\left(s^{t}\right) u\left(T^{j}\left(s^{t}\right), N^{j}\left(s^{t}\right), L^{j}\left(s^{t}\right)\right)
$$


subject to

$$
\begin{aligned}
\sum_{j=1}^{J} T^{j}\left(s^{\imath}\right) & \leq \sum_{j=1}^{J} Y^{j, T}\left(s^{\imath}\right) \quad \forall s^{t}, \\
N^{j}\left(s^{\imath}\right) & \leq Y^{j, N}\left(s^{\imath}\right), \\
L^{j}\left(s^{\imath}\right) & \leq Y^{j \cdot L}\left(s^{\imath}\right),
\end{aligned}
$$

where $\lambda^{j}$ is the social planner's weight on country $j$ utility, $\rho$ is the discount rate, and $\pi\left(s^{i}\right)$ is the probability of state $s^{8} .{ }^{6}$ Furthermore, $Y^{j . T}\left(s^{t}\right), Y^{j . N}\left(s^{\ell}\right)$, and $Y^{j . L}\left(s^{t}\right)$ are, respectively, country $j$ 's output levels of tradables, nontradables, and leisure in state $s$ at time $t$. While the $Y^{j}$ may be viewed as endowments, this view is not necessary since in a production economy a social planner would optimize output efficiently over time and the resulting output levels would have to satisfy the constraints in equation (1).

The first-order conditions with respect to tradables are

$$
\rho^{t} \lambda^{j} u_{T}\left(T^{j}\left(s^{t}\right), N^{j}\left(s^{t}\right), L^{j}\left(s^{t}\right)\right)=\mu\left(s^{t}\right),
$$

where $u_{T}$ is the marginal utility with respect to tradables and $\mu\left(s^{t}\right)$ is the Lagrangian multiplier on the tradables constraint in (1) over the probability of the state. Taking the ratio of first-order conditions with respect to tradables at time $t$ relative to those at $t-1$ gives

$$
\frac{\rho u_{T}\left(T^{j}\left(s^{t}\right), N^{j}\left(s^{t}\right), L^{j}\left(s^{t}\right)\right)}{u_{T}\left(T^{j}\left(s^{t-1}\right), N^{j}\left(s^{t-1}\right), L^{j}\left(s^{t-1}\right)\right)}=\frac{\mu\left(s^{t}\right)}{\mu\left(s^{t-1}\right)} .
$$

Equation (3) says that the ratio of current to future marginal utility of tradables is equal across countries. To simplify notation below, I adopt the notation that for any variable $\eta, \eta_{t} \equiv \eta\left(s^{t}\right)$.

\section{An Overview of the Regression Tests}

I now posit the regression tests, but below I derive them explicitly from equation (3). The first regression tests I examine are benchmark estimates that treat total aggregate consumption in each country as a single tradable good. In the context of household consumption, Cochrane (1991) shows that, when utility is of the power form, consumption growth rates across individuals must be equal and independent of variables idiosyncratic to the household. Thus, when aggre-

${ }^{6}$ In a previous version, I allowed for different discount rates, $\rho^{j}$, across countries. This modification introduces a fixed country effect in the panel estimation but does not alter the main conclusions of the empirical evidence. 
gate consumption is treated as a single tradable good, the regression test could be written as

$$
\Delta \ln \left(T_{t}^{j}\right)=\theta_{0}(t)+\beta X_{t}^{j}+u_{t}^{j},
$$

where $\Delta \eta_{t} \equiv \eta_{t}-\eta_{t-1}$ for any variable $\eta, \theta_{0}(t)$ measures the common growth rate of the Lagrangian in equation (3), $X_{t}^{j}$ is any idiosyncratic variable to country $j$ realized at time $t$, and $u_{t}^{j}$ is a composite error term including measurement error and shocks to preferences. Risk sharing is tested by the hypothesis that $\beta=0$.

Equation (3) suggests why this simple framework does not work in the presence of nontradable leisure or goods. In this case, the marginal utility of tradables consumption is equated across countries, but this marginal utility depends on nontradables. Since the MaceCochrane approach does not control for nontradables, these variables are likely to be correlated with idiosyncratic effects measured by $X_{t}^{j}$, thereby biasing estimates of $\beta$. To control for these variables, I examine regressions of the form

$$
\Delta \ln \left(T_{\ell}^{j}\right)=\theta_{0}(t)+\theta_{1} \Delta \ln \left(N_{t}^{j}\right)+\theta_{2} \Delta \ln \left(L_{\ell}^{j}\right)+\beta X_{t}^{j}+u_{t}^{j} .
$$

In this subsection, I consider the extent to which correcting for these effects on marginal utility minimizes the bias toward rejecting risk sharing in the $\beta$ coefficients. In the next subsection, I investigate an alternative hypothesis: that the finding of nonzero $\beta$ 's in the cross section of countries is driven by countries that face explicit international capital market controls.

\section{Deriving the Regression Test from the First-Order Condition: An Example}

The regression test in (5) controls generally for nontradables that act as taste shocks to the marginal utility of tradables. This regression is a log-linearized form of the marginal utility of tradables. Any approximation error will appear in the error term, $u_{t}^{j}$, introducing measurement error. The estimates below show that if measurement error explains all the risk-sharing rejections, then this measurement error is essentially uncorrelated with nontradable leisure and goods. Therefore, the effects of this approximation error on $\beta$ estimates do not appear to be important.

While the regression test in (5) is valid for any log-linearization of (3), Baxter and Jermann (1994) describe a utility function that provides a useful interpretation of this regression test:

$$
u\left(T_{t}^{j}, N_{t}^{j}, L_{t}^{j}\right)=b_{t}^{j} \psi\left(T_{t}^{j}, N_{t}^{j}\right)^{1-\gamma} \frac{v\left(L_{t}^{j}\right)}{1-\gamma},
$$


where $\psi(T, N)$ is a linearly homogeneous aggregator function, and $\mathbf{I}$ have included a country-specific shock to preferences, $b_{t}^{j}$, that is insurable at time 0 . Taking the marginal utility of $(6)$ with respect to tradables gives

$$
u_{T}\left(T_{t}^{j}, N_{t}^{j}, L_{t}^{j}\right)=b_{t}^{j} \psi\left(T_{t}^{j}, N_{t}^{j}\right)^{-\gamma} \psi_{T}\left(T_{t}^{j}, N_{t}^{j}\right) v\left(L_{t}^{j}\right) .
$$

Substituting equation (7) into (3), taking the natural logarithm of the result, and using the approximations in Baxter and Jermann (1994) gives the first-order conditions as

$$
\begin{aligned}
\Delta \ln \left(T_{t}^{j}\right)= & -c \Delta \ln \left(\mu_{t}\right)+c \ln (\rho)-c\left(1-x_{T}\right)\left(\gamma-\zeta_{T N}^{-1}\right) \Delta \ln \left(N_{t}^{j}\right) \\
& +c \delta_{\psi L} \Delta \ln \left(L_{t}^{j}\right)+u_{t}^{j},
\end{aligned}
$$

where $c \equiv\left\{\gamma x_{T}+\left[\left(1-x_{T}\right) / \zeta_{T N}\right]\right\}^{-1}, x_{T}$ is the share of tradables in expenditures, $\zeta_{T N}$ is the elasticity of substitution between tradables and nontradables, $\delta_{\psi L}$ is the elasticity of the marginal utility of the consumption aggregate with respect to leisure, and $u_{t}^{j}=$ $c \ln \left(b_{t}^{j} / b_{t-1}^{j}\right)+u_{t}^{j \prime}$, the composite of the growth of the insured taste shocks and the measurement error defined as $u_{t}^{j^{\prime}} .{ }^{7}$ According to the first-order conditions, the relationship between the growth rates of tradables and nontradables is governed by the interaction between the inverse of the elasticity of substitution between tradables and nontradables, $\zeta_{T N}^{-1}$, and the parameter of relative risk aversion, $\gamma$.

Comparing (8) and (5) makes clear the specific form of the coefficients. In particular, $\theta_{0}(t)=-c\left[\Delta \ln \left(\mu_{t}\right)-\ln (\rho)\right]$, a constant at time $t ; \theta_{1}=\left(\zeta_{T N}^{-1}-\gamma\right) /\left\{\zeta_{T N}^{-1}+\left[\gamma x_{T} /\left(1-x_{T}\right)\right]\right\} ;$ and $\theta_{2}=c \delta_{\psi L}$. This functional representation of the coefficients allows me to compare my estimates of the elasticity of tradables and nontradables with existing estimates in the literature. I return to this interpretation below.

\section{B. Regression Tests Using Aggregate Total Consumption}

I begin by testing for risk sharing using total consumption data aggregated across goods, referred to as "aggregate consumption" below. Using aggregate consumption as the left-hand-side variables of the

${ }^{7}$ Since $\psi$ is linearly homogeneous,

$$
\Delta \ln \left[\psi\left(T_{t}^{j}, N_{t}^{j}\right)^{-\gamma}\right]=-\gamma\left[x_{T} \Delta \ln \left(T_{t}^{j}\right)+\left(1-x_{T}\right) \Delta \ln \left(N_{t}^{j}\right)\right]
$$

and

$$
\Delta \ln \left[\psi_{T}\left(T_{t}^{j}, N_{t}^{j}\right)\right]=-\left(1-x_{T}\right) \frac{\Delta \ln \left(T_{t}^{j}\right)-\Delta \ln \left(N_{t}^{j}\right)}{\zeta_{T N}} .
$$

Also, $\Delta \ln \left[v\left(L_{t}^{j}\right)\right]=\delta_{\psi L} \Delta \ln \left(L_{t}^{j}\right)$. Substituting these approximations into the logarithm of (3) using (7) gives (8). 
regression as in (5) is clearly incorrect since durables and nontradables are also components in the total. I nevertheless start with tests on aggregate consumption for three reasons. First, the results can be directly compared with those of other studies in the literature on international consumption risk sharing that have used the same data. Second, aggregate data are available for more countries at a higher frequency than the disaggregate data to be examined below. Third, the aggregate data allow me to ask whether disaggregation is necessary at all if market restrictions are used to explain the cross-country consumption comovements. I address this issue in Section II.

\section{The Aggregate Data}

I use the Penn World Tables data set version 5.6 to obtain comparable data series across countries and over time. An earlier version is described in Summers and Heston (1991). Following Obstfeld (1994a, 1994b), I exclude the countries with data quality rated C - and below. The panel data set provides annual observations for the remaining 72 countries over 43 years from 1950 to $1992 .^{8}$ The consumption and output data series used in the analysis below are the per capita real variables measured in terms of a 1985 composite index. ${ }^{9}$

I use domestic output growth demeaned by the aggregate of world output in each period as candidate measures of a country-specific variable, denoted $X_{t}^{j}$ above. A problem with this variable is that measurement error in domestic output is likely to be correlated with measurement error in domestic consumption. I focus on output despite this problem for three reasons.

First, a finding that the hypothesis $\beta=0$ cannot be rejected may simply result from low power, particularly if $X_{t}^{j}$ is a noisy measure of country-specific risk. Using a measure such as output containing measurement error that is likely to be correlated with the measurement error in consumption implies that when I cannot reject that $\beta=0$, this result is fairly strong evidence in favor of risk sharing. At the same time, a finding that $\beta \neq 0$ can be evaluated under the alternative view that all of the rejection is due to measurement error.

Second, Backus et al. (1992) and others in the international business cycle literature have found that output growth rates are more highly correlated internationally than consumption growth rates. Using output growth rates as measures of idiosyncratic shocks focuses

${ }^{8}$ A number of countries have years with missing observations, particularly over the early years. Appendix A discusses the treatment of missing values.

9 This series corresponds to the 1985 international dollars consumption and output in the Penn World Tables data set. 
on the related correlation between consumption and idiosyncratic output.

Third, the deviation of domestic output from world output relates directly to the capital market restrictions tests to be examined below in Section II. The results in this section therefore provide a benchmark for those tests.

\section{The Evidence}

Panel A of table 1 provides summary statistics of these data in annualized percentage growth rates. The mean annual consumption growth rate over the period has been about 1.5 percent with a standard deviation of about 6 percent. Output has experienced somewhat lower variability. The table also shows the mean growth rates and standard deviations of leisure as measured by the unemployment rate. In contrast to the other variables, this variable has a standard deviation of less than 1 percent. It is well known that employment can be difficult to compare across countries. For example, Burdett and Wright (1989) find that the variation in total employment due to the number of workers is much higher in the United States and Canada than for most European countries, where the variation largely comes from hours worked. Given these data problems, the following results may be used to consider whether hours worked are sufficiently different from unemployment to overturn the basic conclusions below.

Panel B of table 1 reports the results of estimating equation (5) with a pooled time-series, cross-section regression for aggregate consumption correcting the standard errors for conditional heteroskedasticity. ${ }^{10}$ The first row reports the results of estimating the equation assuming that consumption and leisure are separable as in equation (4). The column labeled $\beta$ reports the estimate of the coefficient. The point estimate of $\beta$ is close to one at .972 and significantly different from zero at the 95 percent confidence level. Furthermore, idiosyncratic variations in output explain about 59 percent of the variation in idiosyncratic consumption movements.

${ }^{10}$ The standard errors for the parameter vector $\phi$ for the general form of the equation $Y=\phi Z+$ e were estimated according to $\left(Z^{\prime} Z\right)^{-1} \Omega\left(Z^{\prime} Z\right)^{-1}$, where $Z$ is the stacked matrix of right-hand-side variables, and $\Omega \equiv \Sigma_{i=1}^{\tau} Z_{t}^{\prime} e_{t} e_{t}^{\prime} Z_{t}$, where $e_{t}$ and $Z_{t}$ are the vector of errors and right-hand-side variables, respectively, at time $t$, and $\tau$ is the number of observations. In an earlier version of this paper, the time-series data for each country were examined for serial correlation by testing for moving average coefficients in the error term. With the test used in Cumby and Huizinga (1992), the hypothesis that the moving average components equal zero was rejected in less than 5 percent of the countries. Therefore, the errors are assumed here to follow white-noise processes. 
TABLE 1

Risk-Sharinc Tests with Aggregate Consumption

A. Summary Statistics

(Annualized Percentage Growth Rates)

\begin{tabular}{|c|c|c|c|c|}
\hline & \multicolumn{3}{|c|}{ Mean } & $\begin{array}{l}\text { Standard } \\
\text { Deviation }\end{array}$ \\
\hline $\begin{array}{l}\text { Consumption } \\
\text { Output } \\
\text { Leisure }\end{array}$ & \multicolumn{3}{|c|}{$\begin{array}{r}1.456 \\
1.270 \\
.003\end{array}$} & $\begin{array}{r}6.040 \\
4.767 \\
.618\end{array}$ \\
\hline \multicolumn{5}{|c|}{$\begin{array}{l}\text { B. Panel Regressions } \\
=\theta_{0}(t)+\theta_{0} \ln \left(L^{j} / L^{j}\right)\end{array}$} \\
\hline Model & $\theta_{2}$ & $\begin{array}{l}\text { Consumption } \\
\text { Variance } \\
\text { Explained by } \\
\text { Leisure }(\%)^{*}\end{array}$ & $\beta$ & $\begin{array}{c}\text { Consumption } \\
\text { Variance } \\
\text { Explained by } \\
\text { Output }(\%)^{\dagger}\end{array}$ \\
\hline Separable leisure & $\cdots$ & $\cdots$ & $\begin{array}{l}.972^{\ddagger} \\
(.029)\end{array}$ & 58.9 \\
\hline Nonseparable leisure & $\begin{array}{l}.016 \\
(.179)\end{array}$ & $<.1$ & $\begin{array}{l}.972^{\prime} \\
(.029)\end{array}$ & 59.7 \\
\hline
\end{tabular}

Notz.-Data are taken from the Penn Wotld Tables, version 5.6, for employment and per capita consumption and output in 1985 dollars. The sample period is 1985-92 for 72 countries (see App. A). All equations are estimated allowing for conditional heteroskedasticity across countries. Standard errors are in parentheses.

- Calculated as var $\left.\theta_{2} \ln \left(L_{t+1} / L_{t}\right)\right] / \operatorname{var}\left[\ln \left(T_{t+1} / T_{t}\right)-\theta_{0}(t+1)\right]$.

${ }^{+}$Calculated as $\operatorname{var}\left(\beta X_{t+1}\right) / \operatorname{var}\left[\ln \left(T_{t+1} I T_{t}\right)-\theta_{0}(t+1)\right]$.

₹ Significantly different from zero at the 95 percent confidence level.

The second row of panel $B$ relaxes the separability assumption. However, the coefficient on leisure is insignificantly different from zero. Furthermore, the percentage of cross-sectional consumption variation that is explained by leisure is tiny, less than 0.1 percent. Although these data are based on unemployment and should therefore be considered with caution, they suggest that nonseparability between consumption and leisure is unlikely to explain the consumption correlation puzzle. This basic conclusion is consistent with the findings of Backus et al. (1992) using U.S. data alone.

The evidence based on aggregate data suggests a strong rejection of the risk-sharing hypothesis if measurement error is small. On the other hand, if measurement error alone explains these results, the measurement error in output must explain almost 60 percent of the variation in consumption.

The tests reported above combine time-series with cross-sectional evidence. These results could potentially mask a particular outlier in a certain year, causing the overall rejection. To consider this possibility, I estimate equation (4) for each year of the available data. Figure 1 depicts the estimate of $\beta$ as the solid line, with 95 percent confidence bands above and below these estimates. As the figure shows, I reject 


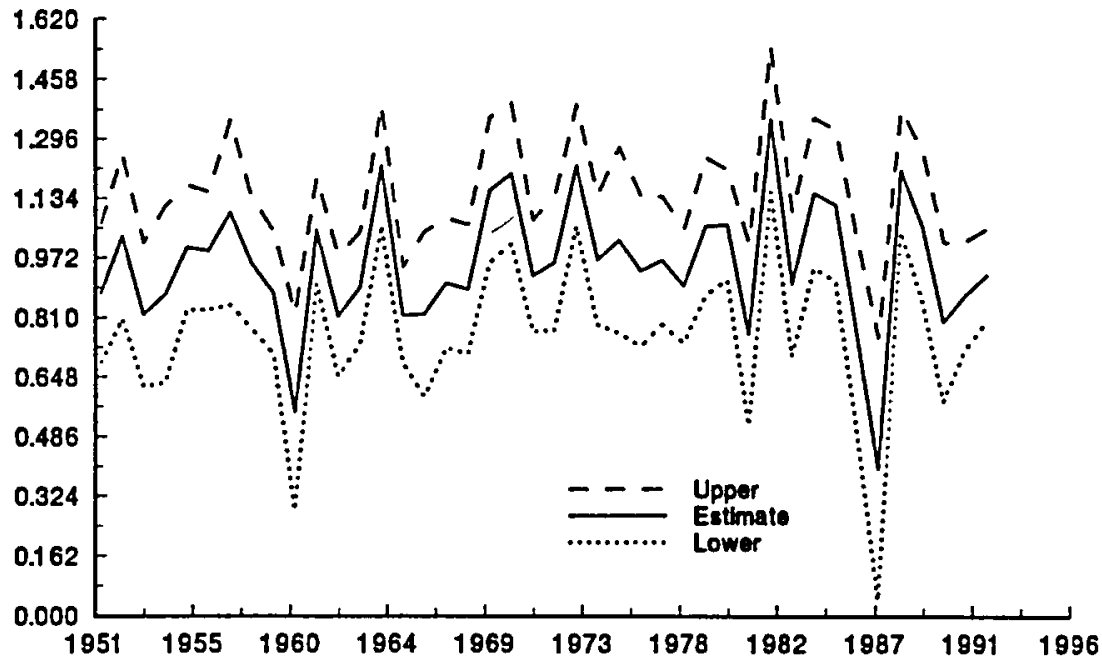

FIc. 1.-Coefficient on income growth

the hypothesis that $\beta=0$ in every year. Thus the evidence against risk sharing in the benchmark case is robust over time.

\section{Regression Tests Using Disaggregated Data}

The evidence using aggregate consumption suggests that risk sharing predicted by complete markets is rejected. However, these tests may reject risk sharing simply because of the idiosyncratic effects of nontradables, a possibility I examine in this subsection.

\section{The Disaggregated Data}

The disaggregated consumption data come from the benchmark studies that underlie the construction of the Summers and Heston (1991) data set. The studies were undertaken for various countries at 5-year intervals beginning in 1970. ${ }^{11}$ These studies involved collecting data on consumption components in a consistent manner across the countries within the study for a given year. The data were collected for four separate years: $1970,1975,1980$, and $1985 .^{12}$ Kravis, Heston, and Summers (1982) describe the methods used in these studies.

"I thank Alan Heston for supplying the original data to me.

12 The numbers of countries and consumption groups for each year are as follows: 1985 has 64 countries and 113 groups, 1980 has 60 countries and 125 groups, 1975 has 34 countries and 108 groups, and 1970 includes only 16 countries and 110 consumption groups. Since the 1990 study did not use the same pricing benchmark across countries within the year as the previous years, I do not use it here. 
From these components, I construct measures of nondurable tradables, nontradables, and durable tradables and then transform the series into per capita units. ${ }^{13}$ The risk-sharing tests require an observation for a country's consumption in two adjacent 5-year intervals. Countries that are in the sample for only one of the four years are eliminated from the sample for purposes of estimation. For the country-specific measure $X^{j}$, I use the domestic output of tradables since the growth rate of tradable goods should be uncorrelated with the domestic output of tradables. The Appendix describes the data in more detail.

\section{The Evidence}

To test for risk sharing using disaggregated data, I estimate a modification of equation (5):

$$
\Delta_{5} \ln \left(T_{t}^{j}\right)=\theta_{0}(t)+\theta_{1} \Delta_{5} \ln \left(N_{t}^{j}\right)+\beta X_{t}^{j}+u_{t}^{j}
$$

where $\Delta_{5} \eta_{t} \equiv \eta_{t}-\eta_{t-5}$ for any variable $\eta$ so that equation (9) is written in 5-year growth rates. Also, I treat leisure as separable by setting its coefficient in equation (5), $\theta_{2}$, equal to zero. ${ }^{14}$

Panel A of table 2 provides summary statistics on the disaggregated data. The standard deviations are substantially larger than those in table 1, in part because the observations pertain to only four periods and cover a smaller subset of countries.

Panel B reports the results of estimating equation.(9). ${ }^{15}$ The first row assumes that tradables and nontradables are separable so that nontradables have a coefficient of zero. As reported, the evidence against risk sharing is similar to the case of consumption aggregates. Nondurable tradable consumption is significantly related to the domestic output of tradables. Furthermore, the percentage of variation

${ }^{13}$ In an earlier version of the paper, I also disaggregated consumption by a fourth group, semidurables, which included items such as shoes, tires, and clothing. Since these commodities are likely to be nondurable over the 5-year periods I examine, I incorporate this series into the nondurable tradables series here. However, none of the main results below is affected by either treating the commodities as durables on the right-hand side or excluding them from the analysis altogether.

14 When leisure is included, the estimates of $\theta_{2}$ are never significantly different from zero and the variability of leisure is only a tiny fraction of the consumption variation, as found in table 1 . Since the estimates on the other coefficients are not affected by the exclusion of leisure, I simply exclude leisure to focus on the nonseparabilities arising from consumption components.

${ }_{13}$ I have also conducted the risk-sharing tests using aggregate data over these same periods to make sure that differences do not arise from differences in 5-year relative to 1-year horizons. Since the evidence is similar to that in table 1, I report only the disaggregated results in table 2. 
TABLE 2

Risk-Siharing Tests with Disaggrecate Consumption

A. Summary Statistics

(Annualized Percentage Growth Rates)

\begin{tabular}{|c|c|c|c|c|}
\hline \multirow[b]{2}{*}{ Summary Statistic } & \multicolumn{3}{|c|}{ CoNSUMPTION COMPONENTS } & \multirow[b]{2}{*}{$\begin{array}{c}\text { Tradable } \\
\text { Output }\end{array}$} \\
\hline & $\begin{array}{l}\text { Nondurable } \\
\text { Tradables }\end{array}$ & $\begin{array}{l}\text { Durable } \\
\text { Tradables }\end{array}$ & Nontradables & \\
\hline $\begin{array}{l}\text { Mean } \\
\text { Standard deviation } \\
\text { Expenditure shares }\end{array}$ & $\begin{array}{r}5.67 \\
16.17 \\
.593\end{array}$ & $\begin{array}{r}7.86 \\
31.09 \\
.064\end{array}$ & $\begin{array}{r}3.00 \\
31.68 \\
.343\end{array}$ & $\begin{array}{l}4.94 \\
23.98 \\
\cdots\end{array}$ \\
\hline \multicolumn{5}{|c|}{$\begin{array}{c}\text { B. Panel Regressions } \\
\ln \left(T_{t}^{j} / T_{t-3}^{j}\right)=\theta_{0}(t)+\sum_{i=1}^{k} \theta_{i} \ln \left(Z_{1}^{i} / Z_{i-3}^{i}\right)+\beta X_{i}^{j}+u_{i}^{j}\end{array}$} \\
\hline$Z^{j}$ & $\theta_{i}$ & $\begin{array}{r}\text { Consumpti } \\
\text { Variance } \\
\text { Explaine } \\
\text { by } Z(\%)\end{array}$ & $\beta$ & $\begin{array}{l}\text { Consumption } \\
\text { Variance } \\
\text { Explained by } \\
\text { Output }(\%)^{\dagger}\end{array}$ \\
\hline 1. None (separable u & $\cdots$ & $\cdots$ & $\begin{aligned} .587^{\dagger} \\
(.084)\end{aligned}$ & 71.5 \\
\hline 2. Nontradables & $\begin{array}{l}.017 \\
(.057)\end{array}$ & .1 & $\begin{array}{l}.550^{+} \\
(.071)\end{array}$ & 66.9 \\
\hline 3. Durables & $\begin{array}{l}.169^{\prime} \\
(.033)\end{array}$ & 10.3 & $\begin{array}{r}.412^{4} \\
(.052)\end{array}$ & 37.4 \\
\hline $\begin{array}{l}\text { 4. All: } \\
\text { Nontradables }\end{array}$ & $\begin{array}{l}.029 \\
(.052)\end{array}$ & & . & \\
\hline Durables & $\begin{array}{l}.170^{+} \\
(.041)\end{array}$ & 12.8 & $\begin{array}{l}.380^{+} \\
(.077)\end{array}$ & 31.9 \\
\hline
\end{tabular}

Note.-Data are taken from the 5-year benchmark studies used in the Penn World Tables for disaggregated consumption expenditures in current international dollars. The data are converted into 1985 dollars using the ratio of the U.S. current dollar consumption to the U.S. 1983 dollar consumption in the Penn World Tables. The sample years are 1970, 1975, 1980, and 1985 for 48 countries (not all countries have data in each year, as described in App. A). All equations are estimated allowing for conditional heteroskedasticity. Standard errors are in parentheses.

* Calculated as var $\left[\Sigma_{i=1}^{3} \theta_{i} \ln \left(Z_{i}^{j} / Z_{1-3}^{i}\right)\right] / \operatorname{var}\left[\ln \left(T_{i} / T_{t-3}\right)-\theta_{0}(t)\right]$.

+ Calculated as var $(\beta Y) / v a r\left[\ln \left(T_{t} / T_{t-3}\right)-\theta_{0}(t)\right]$.

\$ Significantly different from zero at the 95 percent confidence level.

in consumption explained by output at 71.5 percent is even higher than that of the consumption aggregates.

The second row reports the same estimates allowing for nontradables. Given the recent interest in nontradables as an explanation of the consumption correlation puzzle, it is perhaps surprising that nonseparabilities between tradables and nontradables are not significant. The coefficient $\theta_{1}$ is insignificantly different from zero, and the variation in nontradables explains only 0.1 percent of the variation in tradables. 
Under risk sharing and the utility function in (6), the estimate of $\theta_{1}$ is a function of the elasticity of substitution, $\zeta_{T N}$, the parameter of relative risk aversion, $\gamma$, and the ratio of nontradables consumption share to tradables, $x_{T} /\left(1-x_{T}\right)$. Therefore, with values for $\gamma$ and the shares, I can back out an estimate of the elasticity of substitution using the expression for the coefficient on nontradables in equation (8). Since the expenditure share of nondurable tradables is .593 , the inverse of the elasticity of substitution for $\gamma=2$ has a point estimate of 2.1 in a confidence range of $1.48-2.88$. This range is consistent with point estimates in the literature as described by Baxter, Jermann, and King (1994).

On the other hand, since tradables consumption growth is significantly correlated with domestic output growth, the evidence rejects risk sharing and therefore equation (9). A possible explanation is that durables and nondurables are not separable, a maintained assumption I now relax.

\section{Incorporating Durables}

Durables may affect the results above since the correlation of domestic nondurable tradables may pick up the effects of durable tradable services that are not separable in the utility function. While durable goods are certainly tradable, the services on these goods are unlikely to be. For example, the rental markets in cars, household appliances, and furniture in most cases do not cross national boundaries. Since previous studies have combined durables and nondurables into measures of tradables, these studies treat the expenditures as equivalent to services and both measures as tradables. If some part of services on durables is nonseparable in utility, however, then the coefficient on output in (9) may differ from zero because of omitted variables bias.

I therefore rewrite equation (9) controlling for durables, $D_{t}^{j}$, on the right-hand side as

$$
\Delta_{5} \ln \left(T_{t}^{j}\right)=\theta_{0}(t)+\theta_{1} \Delta_{5} \ln \left(N_{t}^{j}\right)+\theta_{2} \Delta_{5} \ln \left(D_{\imath}^{j}\right)+\beta X_{t}^{j}+u_{t}^{j},
$$

where now $\theta_{2}$ would reflect the elasticities of substitution of durables if these variables were used in the test. Since durables services are not observable, however, I use the expenditures on durables as proxies for the underlying variation in durables services. Since they can be poor measures of services, the estimates of $\theta_{i}$ cannot be interpreted in terms of parameters in the utility function.

Row 3 of panel $B$ reports the estimates assuming separability between nondurable tradables and nontradables so that $\theta_{1}=0$. In this case, durables are significantly correlated with nondurable tradables 
and represent a higher proportion of variation in nondurable tradables than conventional nontradables do at 10.3 percent. However, risk sharing is rejected.

Row 4 reports the estimates including both nontradables and durables to allow for potential omitted variables bias in the nontradables regressions. As these estimates show, the combined components of consumption explain 12.8 percent of the variation of tradables consumption, and a lower proportion is explained by output at 32 percent. ${ }^{16}$ Risk sharing continues to be rejected.

\section{Conclusions about Nonseparabilities}

The evidence to this point shows that risk-sharing tests allowing for nonseparabilities are rejected. If measurement error is the reason for this rejection, the evidence shows how this error must behave. According to table 2, the error must be essentially uncorrelated with nontradables but should be significantly correlated with durables and tradables output. Furthermore, it must explain at least 32 percent of the variation of tradables consumption, or greater than the other components of consumption combined.

Alternatively, under the view that measurement error is not the sole source of the rejection, tables 1 and 2 suggest that nonseparabilities in utility cannot explain the low cross-country correlation in consumption on their own. Including measures of leisure, nontradables, and durables services helps to explain the puzzle by accounting for up to about an eighth of the variation in consumption growth rates. However, even after all these nonseparabilities are incorporated, nondurables tradables consumption is significantly related to output. Therefore, while nonseparabilities help to explain the puzzle, they do not appear to be enough.

\section{Can Capital Market Restrictions Explain It?}

The nonseparabilities explanation is based on the presumption that all countries have equal access to international capital markets. In this section, I examine whether violations of this presumption may help explain the risk-sharing rejections.

Examples of restrictions on international capital markets are readily available. In addition to standard domestic market frictions such as transactions costs, liquidity constraints, and short-sale con-

${ }^{16}$ When I decompose consumption into semidurables and control for these goods on the right-hand side, nonseparabilities explain up to about 36 percent of the variation in tradables, although risk sharing is rejected. 
straints, participation by domestic residents in international capital markets is often affected by taxes and government restrictions on the holdings of foreign assets. Furthermore, residents of countries may be restricted from borrowing in international markets because of past defaults on loans by their government or other domestic residents. The debt crisis in Latin America during the early 1980s serves as a clear example.

Of course, restrictions either by governments or by international markets do not necessarily affect consumption if domestic residents are able to circumvent these restrictions. ${ }^{17}$ Therefore, whether capital market restrictions are important is an empirical question I address next.

\section{A. Based on a Single Tradable Good}

I begin by assuming that there is a single tradable good as in table 1 and define $D(j, t)$ as an indicator variable that is one if country $j$ is restricted at time $t$ and is zero otherwise. Then I consider regression tests of the form

$$
\Delta \ln \left(T_{t}^{j}\right)=\theta_{0}(t)+\beta^{r} D(j, t) X_{t}^{j}+\beta^{u}[1-D(j, t)] X_{t}^{j}+u_{t}^{j},
$$

where $\beta^{u}$ is the coefficient on output variations in unrestricted countries and $\beta^{r}$ is the corresponding coefficient for restricted countries. I next show that a test of capital market restriction is the hypothesis that $\beta^{r}>\beta^{u}=0$.

\section{Developing the Test}

To examine the effects of restrictions on the risk-sharing rejections, consider the regression tests in (4) using aggregate consumption and assuming separability, repeated here for convenience:

$$
\Delta \ln \left(T_{t}^{j}\right)=\theta_{0}(t)+\beta X_{t}^{j}+u_{t}^{j}
$$

By ordinary least squares, $\beta=\operatorname{cov}\left[\Delta \ln \left(T_{t}^{j}\right), X_{t}^{j}\right] / \operatorname{var}\left(X_{t}^{j}\right)$. In other words, the sign of $\beta$ is determined by the covariance between the growth rate of the consumption good, $\Delta \ln \left(T_{t}^{j}\right)$, and domestic output relative to the world, $X_{l}^{j}$.

Recent studies of market frictions suggest that various types of restrictions will increase the covariance between consumption and idiosyncratic income relative to complete markets. In Clarida (1990),

${ }^{17}$ As pointed out by Heaton and Lucas $(1992,1995)$, Telmer (1993), and others, if investors have access to an unrestricted asset, then restrictions such as transactions costs or, in the present case, taxes on other assets may have little effect on consumption and asset prices. 
borrowing restrictions induce a positive covariance between domestic output and consumption for restricted countries. This positive covariance has also been suggested by studies of market frictions at the individual level. ${ }^{18} \mathrm{~A}$ higher covariance between consumption and idiosyncratic disturbances implies that the coefficient on output in the regression (4) should be positive for countries facing international market restrictions. Thus, if the intuition from these studies holds, $\beta^{r}>\beta^{u}=0$.

Countries with capital market restrictions typically restrict domestic residents from ownership of foreign equity, from borrowing and lending abroad, or from both. Below, I use a data set compiled by the International Monetary Fund that indicates whether domestic residents face these types of restrictions. To motivate tests using these restrictions, I next determine the sign of the regression coefficient of restricted countries, $\beta^{r}$, when these countries are small and take the world price of equities as given.

\section{Theoretical Motivation}

I first assume that a government imposes a tax on holdings of foreign equities. This restriction basically introduces a cost on holdings of foreign equities. Thus transactions costs or other types of market frictions can also be captured by this "tax."

To think about the decentralized country-specific equilibrium behind equation (1), I suppose that production is given by endowments that accrue to residents of each country. Wealth is held in the form of domestic and foreign equities that pay out dividends on realizations of the consumption good in the respective countries.

Residents in each individual country $j$ maximize an intertemporal utility function

$$
E_{t}\left\{\sum_{r=1}^{\infty} \rho^{r} u\left(T_{t+r}^{j}\right)\right\}
$$

subject to

$$
\begin{aligned}
T_{t}^{j}+p_{t} b_{t}^{j}+\chi_{t}^{j} q_{t}+\chi_{t}^{* j} q_{t}^{*} \leq & b_{t-1}^{j}+\chi_{t-1}^{j}\left(q_{t}+Y_{t}\right) \\
& +\chi_{t-1}^{* j}\left(q_{t}^{*}+Y_{t}^{*}\right)(1-\kappa),
\end{aligned}
$$

${ }^{18}$ Cuoco and Cvitanic (1995) show theoretically for the case of log utility that general types of restrictions on risky assets will bias holdings of these assets toward zero and hence increase the covariance of consumption and idiosyncratic income relative to complete markets. With iso-elastic utility, Heaton and Lucas (1992) find in simulation results that the covariance between consumption and idiosyncratic income increases relative to complete markets as various types of market frictions are imposed, including transactions costs and borrowing constraints. 
where $b_{t}$ is domestic holdings of an internationally traded pure discount bond that pays out one unit of the consumption good at time $t+1, p_{t}$ is its price, $\chi_{t}^{j}$ is domestic holdings of the domestic equity that pays the output stream $Y_{t}^{j}, q_{t}$ is its price, $\chi_{l}^{* j}$ is domestic holdings of the foreign equity that pays out the composite foreign output stream, and $Y_{t}^{*}=\sum_{i=1}^{J} Y_{t}^{i}-Y_{t}^{j}$.

In (12), $\kappa$ represents the proportional direct or indirect tax placed on domestic residents who want to hold foreign equity. It is well known that for iso-elastic utility, when $\kappa=0$, all countries will hold the same portfolios of a world mutual fund and, hence, share the same consumption growth rates as implied by (3). ${ }^{19}$ On the other hand, when domestic residents face the foreign equity tax, they bias their holdings toward more domestic equities and, hence, toward domestic output. Appendix B shows that this bias induces a higher covariance of consumption with country-specific output so that $\beta^{r}>$ $\beta^{u}=0$.

\section{The Evidence}

I take measures of the presence of restrictions from the International Monetary Fund's Annual Report on Exchange Restrictions and Exchange Arrangements. ${ }^{20}$ The annual report summarizes types of restrictions into broad categories that unfortunately do not allow a precise definition of the restriction for each country. Two of these measures are related to capital market movements. ${ }^{21} \mathrm{~A}$ third measure corresponds to countries that are likely to face borrowing constraints. Panel A of table 3 provides summary information about each of these measures, and Appendix A provides further details.

Column 1 reports information about restrictions on capital transactions over the period $1966-92 .{ }^{22}$ This series incorporates all countries that impose quantity or tax restrictions on acquisitions or holdings of foreign assets. As such, these restrictions vary from mild to severe. The column shows the average proportion of years in which one of the members of different country groups had a restriction on capital transactions. This proportion ranges from .39 on the low side for the

${ }^{19}$ For example, Ingersoll (1987) describes a mutual fund theorem in which all investors with the same iso-elastic utility would hold the same portfolio shares. Lewis (1995) describes the implications of this theorem in the international context.

${ }^{20}$ I thank Andy Rose for giving me most of this data set.

21 The report also contains information about goods market restrictions that are not considered in this paper.

${ }_{22}$ Although the series begins in 1966, the year-by-year results in fig. 1 and the table 2 results using data from 1970 to 1985 show that the basic findings in table 1 are not sensitive to beginning the sample in $\mathbf{1 9 5 0}$. 
TABLE 3

Tests of Market Restrictions on Risk Sharinc Using aggregate Consumption A. Average Restrictions

(as Proportion of One)

\begin{tabular}{lccc}
\hline \hline & \multicolumn{3}{c}{ Restriction Mieasure } \\
\cline { 2 - 4 } Group & $\begin{array}{c}\text { On Capital } \\
\text { Transactions* } \\
(1)\end{array}$ & $\begin{array}{c}\text { Payment } \\
\text { Arrangements* } \\
(2)\end{array}$ & $\begin{array}{c}\text { Interest } \\
\text { Arrears } \\
(3)\end{array}$ \\
\hline Group of Seven & .392 & .005 & .000 \\
Continents: & .984 & .178 & .414 \\
Africa & .596 & .074 & .500 \\
North and Central Americas & .641 & .344 & .529 \\
South America & .736 & .432 & .076 \\
Asia & .752 & .268 & .043 \\
Europe & .667 & .000 & .000 \\
Oceania & & & \\
\hline
\end{tabular}

B. Panel Regressions

$\ln \left(T_{t}^{j} / T_{t-1}^{j}\right)=\theta_{0}(t)+\beta^{r} D(j, t) X_{t}^{j}+\beta^{u}[1-D(j, t)] X_{\imath}^{j}+u_{t}^{j}$

\begin{tabular}{|c|c|c|c|}
\hline $\begin{array}{l}\text { Restriction Measure } \\
\qquad(D(j, t))\end{array}$ & $\beta^{r}$ & $\beta^{*}$ & $\begin{array}{c}\text { Marginal } \\
\text { Significance } \\
\text { Level } \\
H_{0}: \beta^{\prime}=\beta^{*}\end{array}$ \\
\hline On capital transactions & $\begin{array}{l}1.01^{\ddagger} \\
(.02)\end{array}$ & $\begin{array}{l}.92^{\ddagger} \\
(.04)\end{array}$ & .037 \\
\hline Bilateral payment arrangements & $\begin{array}{l}1.09^{\ddagger} \\
(.04)\end{array}$ & $\begin{array}{r}.96^{\ddagger} \\
(.02)\end{array}$ & .003 \\
\hline Interest arrears & $\begin{array}{l}.95^{4} \\
(.07)\end{array}$ & $\begin{array}{l}.67^{\ddagger} \\
(.06)\end{array}$ & .004 \\
\hline
\end{tabular}

Note.-Consumption and output data are the same as in table l over the period 1966-92, coinciding with the restrictions data. The restrictions data are taken from the International Monetary Fund's Annual Report on Exchange Arrongements and Exchange Restrictions. Standard errors are in parentheses.

- For the period 1966-92.

- For the period of data availability. 1986-92.

t Significantly different from zero at the 95 percent confidence level.

Group of Seven to .98 on the high side for Africa. Clearly, capital restrictions of some form have been prevalent over the period. Figure 2 shows how the proportion of restricted countries has varied over time.

One problem with this measure is that it treats equally restrictions of different degrees. Some examples of countries categorized as restricted by this measure are provided in Appendix A. Since so much of the world faces restrictions of this sort, I also examine restrictions that are less general. Therefore, the second measure of restrictions I consider is a less direct measure intended to capture difficulties with payments arrangements. Some countries have currencies that 


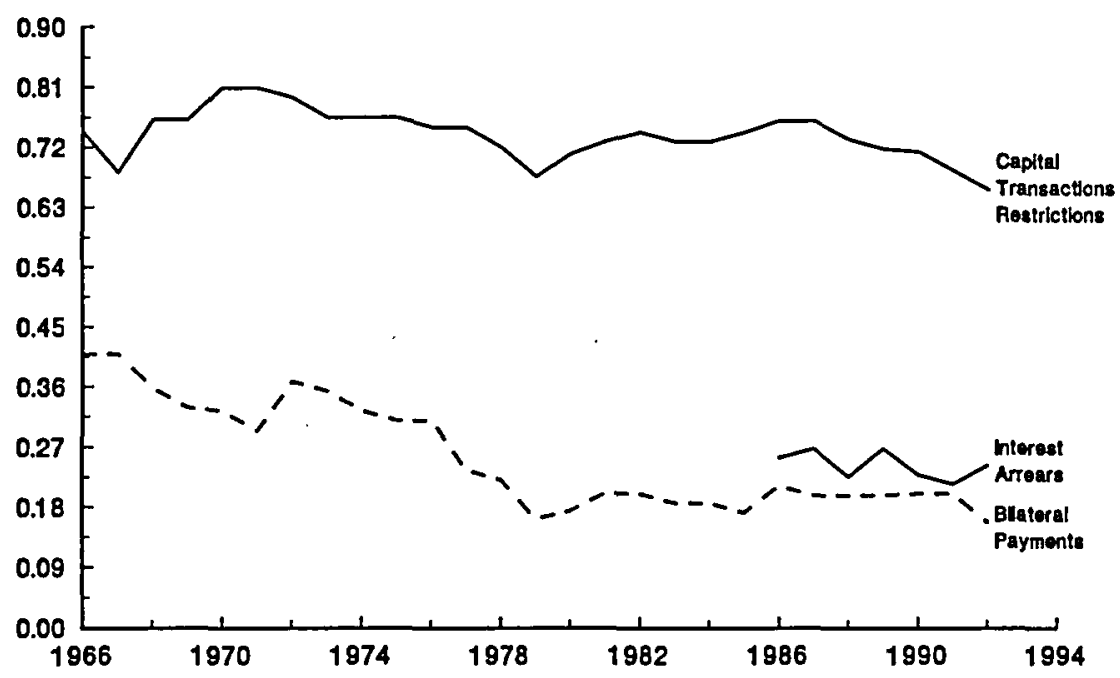

FIC. 2.-Proportion of countries with international capital market restrictions

are not heavily tradable in international markets and therefore have so-called bilateral payments arrangements with certain countries. Under these arrangements, payments for goods can be made with other goods in lieu of currency payments. Residents in countries who find it necessary to enter into this type of arrangement rather than using international currency payments may face higher costs of transacting in world capital markets as well.

Column 2 of panel A reports the proportion of these countries across the world. This proportion ranges from zero and near zero for Oceania (New Zealand and Australia) and the Group of Seven, respectively, to .43 for Asia. Clearly, this measure captures a smaller subset of countries and, perhaps, more severe restrictions than the other capital market restrictions measure. Figure 2 shows that the proportion of restricted countries by this proxy has decreased over time.

A third measure of capital market restrictions in panel $A$ is an indicator that countries are in interest arrears. Countries that are not current on interest payments are likely to be constrained from borrowing and potentially from other types of international capital market transactions as well. Reporting of these data began only in 1986 so that this series has a shorter sample period than the other two capital market restrictions series. Panel A reports the composition of countries in interest arrears by group, and figure 2 shows how the overall proportion of countries in interest arrears has changed over 
time. As the table shows, the highest concentration of countries in interest arrears has been in South and Central America, with African countries coming in close behind..$^{23}$

Panel B reports the results of the test posed above. For each of the three measures of restrictions, the estimates suggest that $\beta^{r}>\beta^{u}$ and the constraint that $\beta^{r}=\beta^{u}$ is strongly rejected at marginal significance levels of less than 5 percent. On the other hand, the coefficients on the unrestricted countries, $\beta^{u}$, are significantly different from zero. Therefore, restrictions seem to be important even for countries with relatively low restrictions.

In summary, table 3 provides evidence that consumption growth rates in countries facing capital market restrictions covary more strongly with domestic output variations relative to the world than unrestricted countries. This relationship is precisely what a simple model of capital market restrictions on foreign equity holdings would imply. However, risk-sharing tests among countries with relatively unrestricted countries are also rejected. Therefore, these restrictions do not independently explain the lack of risk sharing.

\section{B. Using Disaggregated Data}

One possible explanation for the rejection of risk sharing among unrestricted countries is that aggregate consumption includes nontradables. If these nonseparabilities are important and if some countries find it costly to hold foreign assets that would allow them to risk-share, then the tests above may confound both issues. For this reason, I now consider whether allowing for nonseparabilities and market restrictions can explain the puzzle. I find that they may.

\section{Developing the Test}

According to the social planner's problem, the marginal utility of tradables must be independent of domestic output variation. If domestic residents are restricted from holding foreign equities, however, then tradables risk may not be diversified away internationally so that tradables consumption may be correlated with tradables output, as found in table 2. In this case, the coefficients in the regressions of unrestricted countries should differ significantly from those of restricted countries. Furthermore, if countries with low restrictions are sufficiently diversified, then tradables consumption should be uncorrelated with tradables output for these countries.

I test for this relationship by separating equation (10) according to

${ }^{29}$ Neither the United States nor Canada has been in interest arrears over this period. 
the capital market restrictions measures

$$
\begin{aligned}
\Delta_{5} \ln \left(T_{t}^{j}\right)= & \theta_{0}^{r}(t) D(j, t)+\theta_{0}^{u}(t)[1-D(j, t)] \\
& +D(j, t) \sum_{i=1}^{k} \theta_{i}^{r} \Delta_{5} \ln \left(Z_{t}^{i j}\right) \\
& +[1-D(j, t)] \sum_{i=1}^{k} \theta_{i}^{u} \Delta_{5} \ln \left(Z_{i}^{i j}\right) \\
& +D(j, t) \beta^{r} X_{t}^{j}+[1-D(j, t)] \beta^{u} X_{t}^{j}+u_{t}^{j},
\end{aligned}
$$

where $\left(Z_{l}^{1 j}, Z_{t}^{2 j}\right) \equiv\left(N_{t}^{j}, D_{t}^{j}\right)$. When durables are assumed separable, then $k=1$. For nonseparable durables, $k=2$. If market restrictions are unimportant, then I should find no difference between the two groups so that $\beta^{r}=\beta^{u}$ and $\theta_{i}^{r}=\theta_{i}^{u}$. On the other hand, if market restrictions are important, then I should find $\beta^{r} \neq \beta^{u}$ and $\theta_{i}^{r} \neq \theta_{i}^{u}$. If unrestricted countries are risk sharing in tradables, then I should find that $\beta^{u}=0$; whereas if restricted countries are not, I may find that $\beta^{r} \neq 0$. Note that since $\beta$ is a multiple regression coefficient in (13), its sign and magnitude do not have natural interpretations in terms of restrictions as in the aggregate consumption case.

\section{The Empirical Evidence for Restrictions on Capital Transactions}

Table 4 reports the results of the regression tests in (13) using the disaggregated data from table 2 and the measure of restrictions on capital transactions. ${ }^{24}$ The first row shows the estimates when separability is assumed. Consistent with the evidence in table 2, tradables consumption is significantly related to tradables output, and this result does not depend on whether the country has restrictions. However, allowing for nonseparabilities with respect to nontradables as in the second row significantly alters the results. I strongly reject the hypothesis that restricted countries and unrestricted countries share the same coefficients. The final entry allows for nonseparabilities in durables, also rejecting the hypothesis that the coefficients on the nontradables arguments in utility are the same.

The evidence based on capital transactions restrictions provides mixed evidence in terms of risk sharing. The relationship between tradables and nontradables is significantly different across the two

${ }^{24}$ Since the interest arrears series begins after the disaggregated series, I cannot study this measure of restrictions. 
TABLE 4

Tests of Capital. Transactions Restrictions on Risk Sharinc Using Disaggregate Consumption

$$
\begin{aligned}
\ln \left(T_{t}^{j} / T_{t-3}^{j}\right)= & \theta_{0}^{r}(t) D(j, t)+\theta_{0}^{u}(t)[1-D(j, t)]+D(j, t) \sum_{i=1}^{k} \theta_{i}^{r} \ln \left(Z_{t}^{i} / Z_{t-3}^{i}\right) \\
& +[1-D(j, t)] \sum_{i=1}^{k} \theta_{i}^{u} \ln \left(Z_{t}^{i} / Z_{t-3}^{i}\right)+\beta^{r} D(j, t) X_{t}^{j}+\beta^{u}[1-D(j, t)] X_{t}^{j}+u_{t}^{j}
\end{aligned}
$$

\begin{tabular}{|c|c|c|c|c|c|c|}
\hline$Z^{j}$ & $\theta_{i}^{r}$ & $\theta_{i}^{\mu}$ & $\begin{array}{c}\text { Marginal } \\
\text { Significance } \\
\text { Level } \\
H_{0}: \theta^{r}=\theta^{u}\end{array}$ & $\beta^{r}$ & $\beta^{\prime \prime}$ & $\begin{array}{c}\text { Marginal } \\
\text { Significance } \\
\text { Level } \\
H_{0}: \beta^{r}=\beta^{n}\end{array}$ \\
\hline $\begin{array}{c}\text { 1. None (separable } \\
\text { utility) }\end{array}$ & $\cdots$ & $\cdots$ & $\cdots$ & $\begin{array}{l}.800^{*} \\
(.059)\end{array}$ & $\begin{array}{l}.810^{*} \\
(.068)\end{array}$ & .704 \\
\hline 2. Nontradables & $\begin{array}{l}.613^{*} \\
(.051)\end{array}$ & $\begin{array}{l}.244^{*} \\
(.083)\end{array}$ & $<.001$ & $\begin{array}{l}.208^{*} \\
(.065)\end{array}$ & $\begin{array}{l}.428^{*} \\
(.090)\end{array}$ & $<.001$ \\
\hline $\begin{array}{l}\text { 3. All: } \\
\text { Nontradables }\end{array}$ & $\begin{array}{l}.061 \\
(.086)\end{array}$ & $\begin{array}{l}.035 \\
(.067)\end{array}$ & & & & \\
\hline Durables & $\begin{array}{l}.123^{*} \\
(.049)\end{array}$ & $\begin{array}{l}.650^{*} \\
(.052)\end{array}$ & $<.001$ & $\begin{array}{l}.236^{*} \\
(.081)\end{array}$ & $\begin{array}{l}.394^{*} \\
(.107)\end{array}$ & .362 \\
\hline
\end{tabular}

Nore.-The data are the same as in table 2 for consumption and output and table 3 for capital market restrictions. Standard errors are in parentheses.

* Significantly different from zero at the 95 percent confidence level.

groups of countries, as would be suggested if the restrictions were binding. On the other hand, risk sharing is rejected in all cases since tradables consumption depends significantly on tradables output.

\section{Empirical Evidence for Bilateral Payments Arrangements}

An important problem with the capital transactions restriction measure is that it combines many different levels of restrictions into one measure. As illustrated by figure 2, the unrestricted countries constitute a small part of the world. A degree of risk sharing may take place among unrestricted countries and countries with mild restrictions as measured by the capital market restriction measure. When the two groups are segmented, risk sharing among the unrestricted countries may be rejected simply because countries with mild restrictions are not included in their group.

For this reason, table 5 shows the results of these same tests on the more specific proxy of capital market restrictions, the bilateral payments arrangements measure. As figure 2 shows, countries that maintain these types of arrangements constitute significantly less than 
TABLE 5

Tests of Bilateral Payments Restrictions ox Risk Sharing Using Disaggregate CoNSUMPTION

$$
\begin{aligned}
\ln \left(T_{t}^{j} / T_{t-5}^{j}\right)= & \theta_{0}^{r}(t) D(j, t)+\theta_{0}^{u}(t)[1-D(j, t)]+D(j, t) \sum_{i=1}^{k} \theta_{i}^{\gamma} \ln \left(Z_{t}^{i} / Z_{t-5}^{i}\right) \\
& +[1-D(j, t)] \sum_{i=1}^{k} \theta_{t}^{u} \ln \left(Z_{t}^{i} / Z_{t-5}^{i}\right)+\beta^{r} D(j, t) X_{t}^{j}+\beta^{u}[1-D(j, t)] X_{t}^{j}+u_{t}^{j}
\end{aligned}
$$

\begin{tabular}{|c|c|c|c|c|c|c|}
\hline$Z^{j}$ & $\theta_{i}^{r}$ & $\theta_{i}^{u}$ & $\begin{array}{c}\text { Marginal } \\
\text { Significance } \\
\text { Level } \\
H_{0}: \theta^{\prime}=\theta^{\prime \prime}\end{array}$ & $\beta^{r}$ & $\beta^{u}$ & $\begin{array}{c}\text { Marginal } \\
\text { Significance } \\
\text { Level } \\
H_{0}: \beta^{\prime}=\beta^{u}\end{array}$ \\
\hline 1. None (separable & $\cdots$ & $\cdots$ & $\cdots$ & $\begin{array}{l}.751^{*} \\
(.091)\end{array}$ & $\begin{array}{l}.721^{*} \\
(097)\end{array}$ & .481 \\
\hline 2. Nontradables & $\begin{array}{l}.660^{*} \\
(.219)\end{array}$ & $\begin{array}{l}.596^{*} \\
(.112)\end{array}$ & .762 & $\begin{array}{l}.104 \\
(.181)\end{array}$ & $\begin{array}{c}.078 \\
(.145)\end{array}$ & .852 \\
\hline $\begin{array}{l}\text { 3. All: } \\
\text { Nontradables }\end{array}$ & $\begin{array}{c}-.182 \\
(.287)\end{array}$ & $\begin{array}{l}.030 \\
(.104)\end{array}$ & & & & \\
\hline Durables & $\begin{array}{l}.184 \\
(.141)\end{array}$ & $\begin{array}{l}.768^{*} \\
(.237)\end{array}$ & .037 & $\begin{array}{l}.622^{*} \\
(.115)\end{array}$ & $\begin{array}{c}-.007 \\
(.190)\end{array}$ & .028 \\
\hline
\end{tabular}

NotE.-The data are the same as in table 2 for consumption and output and table $\$$ for capital market restrictions. Standard errors are in parentheses.

- Significantly different from zero at the 95 percent confidence level.

50 percent of the countries in the world, and this percentage has fallen over time.

As in table 4, when utility is assumed to be separable, risk sharing is rejected and the coefficients on tradables output are insignificantly different from each other. However, once nonseparabilities in nontradables are allowed, the effects are striking: risk sharing is not rejected. This result suggests that countries with payments arrangements may provide risk sharing among each other, although it may also result from low power due to the small number of these countries.

Since the relationship between nondurable tradables and nontradables may be affected by omitting durables, row 3 includes this variable. Again, the relationships among the components of consumption are significantly different. It is interesting to note that risk sharing is rejected for the restricted countries but is not rejected for the unrestricted countries!

This result suggests that, first, nonseparabilities in utility between nondurable tradables and other components are important in explaining the differences across restricted and unrestricted countries 
and that, second, countries that are unrestricted appear to be risk sharing in terms of tradables. These results suggest an interesting resolution to risk sharing. Incorrect rejection of risk sharing may result from ignoring nonseparabilities and the importance of market restrictions.

\section{Conclusions}

In this paper, I have asked whether nonseparabilities or market restrictions can explain the lack of international consumption risk sharing observed in the data. The evidence suggests that neither explanation can resolve the risk-sharing puzzle alone. When one considers nonseparabilities and ignores market restrictions, nontradable goods and leisure explain only a tiny fraction of the cross-country variation in tradables consumption. Further, tradables consumption is significantly correlated with country-specific movements in output. When countries are segmented according to whether they face market restrictions, risk sharing tests using aggregate consumption also reject for both sets of countries, although the rejections are stronger for the restricted countries.

Instead of these two individual explanations, the evidence points to a combination of both to explain risk sharing. The relationship between tradables and other components of utility appears to be significantly different for restricted and unrestricted countries. It is striking that risk sharing in tradables is not rejected for unrestricted countries measured by the less general of two market restrictions measures. This result suggests that both nonseparabilities and market restrictions are important for explaining international consumption risk sharing.

\section{Appendix A}

\section{Data Appendix}

\section{A. Annual Data}

The annual data of consumption, output, and leisure were taken from the Penn World Tables data set described in Summers and Heston (1991). Output is the series RGDPCH (real gross domestic product per capita in constant dollars), with 1985 as the base year. Consumption is series $C$, the share of GDP times output. The growth rate of leisure is treated as minus the growth rate in employment. Employment is calculated as the number of workers per equivalent adult, series RGDPEA divided by RGDPW. Countries with missing 
values for a given year are dropped from estimation, including calculation of the fixed time effects.

\section{B. Disaggregated Consumption}

Disaggregated consumption by commodity for years $1970,1975,1980$, and 1985 were taken from the United Nations International Comparison Program described in Summers and Heston (1991). Each year had between 110 and 150 consumption goods categories. These series were also real goods in base year 1985. The categories of goods are described in more detail in Kravis et al. (1982), especially beginning on page 69.

For each year, the consumption categories were aggregated across the individual commodities. A general description of each category follows.

Nondurable tradables. - Includes goods such as basic food items, tobacco products, gasoline and fuels (used in residences), housecleaning supplies, drugs, nondurable recreation, toilet articles, and personal accessories. Tradable goods that are typically associated with semidurables were incorporated into the series since the data are observed only every 5 years. The semidurables include goods such as clothing, footwear, glass and tableware, tires and automobile accessories, radios, photographic equipment, and books and newspapers. The tests in tables 2,4 , and 5 were conducted both including and excluding semidurables, and the main results were not affected.

Durables. - Includes goods such as furniture, floor coverings, refrigerators, washing appliances, and passenger vehicles.

Nontradables. - Includes services such as repair and maintenance of clothing and footwear; rents on housing; repairs on home and glass and tableware; domestic services; services of physicians, dentists, and nurses; maintenance and repair on automobiles; personal transportation services; local taxi rides; theater and sports; hairdresser and barber services; restaurants and cafes; hotels and lodging; and financial services.

A few goods categories were difficult to categorize or showed up in only one year. As a result, they were thrown out of the analysis. The main offenders are hospital care (only in 1970 and 1975), long-distance airfares, and net purchases abroad by tourists.

The raw data are measured in terms of the "current international U.S. prices" as defined in the Penn World Tables. They were converted into per capita 1985 units by deflating with population and the U.S. consumer price index in 1985 relative to those of the other years in the sample.

On the basis of the aggregated components of consumption above, the 5-year growth rates were formed. Countries without adjacent 5-year observations, such as countries in the study for only one year, were excluded. The number of countries remaining in the study is 48 , and the number of observations including the pooled time-series cross section is 71 .

\section{Capital Market Restrictions Data}

The data on capital market restrictions are taken from the summary tables at the end of the International Monetary Fund's Annual Report on Exchange 
Arrangements and Exchange Restrictions (1967-93). These data equal one if there was a restriction during the year, and zero otherwise. Some countries have missing values, and they are treated as in the other cases.

The restrictions on capital transactions measure is defined as "official actions directly affecting the availability or cost of exchange or involving undue delay" ( $n .5$ of the table in the annual report). These restrictions cover many different types of restrictions. For example, the 1990 issue of the annual report gives the following descriptions of capital restrictions. Countries that are "restricted" include Algeria, for which the treatment of "capital" is described as follows: "residents are obliged to repatriate and surrender capital assets (or the sale proceeds thereof) held or acquired outside of Algeria. Capital transfers to any destination abroad are subject to individual license; residents are not normally permitted to acquire capital assets outside of Algeria. All borrowing abroad or from nonresidents must be approved in advance by the Minister of Economy or the Central Bank" (p. 9). Clearly, this constitutes a rather restricted economy.

A less restricted country but one that is considered restricted by the data set is Greece. For Greece, the report say's that "direct investments in Greece by non-EC residents are subject to prior approval, and the repatriation of capital and capital gains is permitted after three years following the realization of the investment. . . . Greek firms are allowed to borrow in foreign exchange without prior approval, provided that the maturity of the loans is at least six months" (p. 185).

On the other extreme, Hong Kong is listed as having no capital restriction in the data set. The discussion of "capital" for Hong Kong says that "no exchange control requirements are imposed on capital receipts or payments by residents or non-residents" (p. 206).

The second measure, bilateral payments arrangements, indicates whether countries have arrangements with other countries for the purpose of paying for goods or capital. For example, in the 1990 report, Hungary is listed as having a bilateral payment arrangement. The report says that "Hungary had bilateral payments agreements with Albania, Brazil, the People's Republic of China, Colombia, Ecuador, Democratic Kampuchea, the Democratic People's Republic of Korea, and the Lao People's Democratic Republic. Hungary also had trade agreements with bilateral features for certain commodities with Afghanistan, Bangladesh, and Pakistan" (p. 209).

Pakistan is also listed in the same year as having a bilateral payments agreement: "Trade transactions under 'barter' agreements are settled through special accounts in nonconvertible currencies. Trade in specified commodities with Bulgaria, the People's Republic of China, Czechoslovakia, Hungary, the Democratic People's Republic of Korea, Poland, Sweden, and the USSR is settled through special nonconvertible accounts" (p. 362). Similar discussions can be found for the other countries. 
Appendix B

Relationship between Coefficient for Restricted and Unrestricted Countries in (11)

Note that the first-order condition with respect to $\chi^{*}$ in (12) implies

$$
u_{T}\left(T_{t}^{j}\right) q_{t}^{*}=\rho E_{\imath}\left[u_{T}\left(T_{t+1}^{j}\right)\left(q_{t+1}^{*}+Y_{t+1}^{*}\right)(1-\kappa)\right] .
$$

Defining $Q_{t} \equiv \rho E_{t}\left[u_{T}\left(T_{t}^{j}\right) / u_{T}\left(T_{t-1}^{j}\right)\right]$, the intertemporal marginal rate of substitution of consumption, and $R_{t}^{*} \equiv\left(q_{t}^{*}+Y_{t}^{*}\right) / q_{t-1}^{*}$, the foreign equity return, and rearranging $(\mathrm{B} 1)$ gives

$$
\operatorname{cov}_{t}\left(Q_{t+1}, R_{t+1}^{*}\right)=\frac{1}{1-\kappa}-E_{t}\left(Q_{t+1}\right) E_{t}\left(R_{t+1}^{*}\right) .
$$

Since this country is small in world markets, the return on the foreign mutual fund, $R^{*}$, and the price of the bond, $p_{t}$, are given. The first-order condition with respect to the bond price implies that $E_{t} Q_{t+1}=p_{t}$. Therefore, by the small country assumption, both $E_{l} Q_{t+1}$ and $E_{t} R_{t+1}^{*}$ are unaffected by the tax. Clearly, then, as the proportional tax increases toward one, equation (B2) shows that the covariance between the intertemporal marginal rate of substitution and the foreign return increases. The reason is that, in equilibrium, residents will be willing to hold the foreign stock with the higher tax rate only when it provides a better hedge against consumption risk at the margin..$^{25}$

Now consider the effects of restrictions on borrowing. Zeldes (1989) shows that in states of the world in which an individual is constrained from borrowing, his expected intertemporal marginal rate of substitution in consumption is lower than is implied by the risk-free rate. The reason is that a liquidity-constrained individual would like to borrow and consume more today relative to the future, thereby pushing up the current relative to future marginal utility of consumption. By equation (B2), for states in which a country is borrowing constrained so that $E_{t} Q_{t+1}$ is lower than its alternative under unrestricted borrowing, the covariance of $Q$ with the foreign equity return will also be higher than under no restriction.

No's the increase in this covariance relative to complete markets can be related to the regression tests as in equation (11). Note that in the steady state, the foreign return $R_{t+1}^{*}$ pays out the sum of total world outputs relative to domestic output. Since the country-specific variable in the regression tests, $X^{j}$, is the logarithm of the deviation of domestic output from the aggregate world economy, the foreign return depends inversely on $X$. In other words, in the steady state, $\ln \left(R_{t+1}^{*}\right) \approx-X_{t}^{j}$ so that in the regression test

${ }^{25}$ Note that in equilibrium, consumption, $T^{j}$, depends on the domestic and foreign equity returns, $R$ and $R^{*}$, so that the covariance of the intertemporal marginal rate of substitution, $Q$, and foreign equities can be changed by increasing holdings of domestic relative to foreign equities, even though the expected movement in $Q$ is determined by world bond markets. 


$$
\begin{aligned}
\beta & =\frac{\operatorname{cov}\left[\Delta \ln \left(T_{t}^{j}\right), X_{t}^{j}\right]}{\operatorname{var}\left(X_{t}^{j}\right)} \\
& \approx-\frac{\operatorname{cov}\left[\Delta \ln \left(T_{t}^{j}\right), \ln \left(R_{t+1}^{*}\right)\right]}{\operatorname{var}\left[\ln \left(R_{t+1}^{*}\right)\right]} .
\end{aligned}
$$

I can therefore ask what happens to $\beta$, the coefficient on $X$, as restrictions on foreign equities increase relative to complete markets, assuming conclitional joint lognormality between $Q$ and $R^{*}$. In this case, the increase in the covariance between the intertemporal marginal utility and the foreign return found in (B2) implies that

$$
\operatorname{cov}_{t}\left(\ln Q_{t+1}, \ln R_{t+1}^{*}\right)=-\gamma \operatorname{cov}_{t}\left[\ln \left(\frac{T_{t+1}^{j}}{T_{t}^{j}}\right), \ln R_{t+1}^{*}\right]
$$

also increases. By joint lognormality,

$$
\begin{aligned}
\operatorname{cov}\left(Q, R^{*}\right) & =E(Q) E\left(R^{*}\right) \exp \left\{\operatorname{cov}\left[\ln (Q), \ln \left(R^{*}\right)\right]-1\right\} \\
& =E(Q) E\left(R^{*}\right) \exp \left\{-\gamma \operatorname{cov}\left[\Delta \ln (T), \ln \left(R^{*}\right)\right]\right\} .
\end{aligned}
$$

Since the covariance between $Q$ and the foreign equity return $R^{*}$ increases with $\kappa$, the covariance between $\log$ consumption growth and the foreign equity decreases. Therefore, $\operatorname{cov}\left[\Delta \ln \left(T_{t}^{j}\right), X_{t}^{j}\right]>0$ and $\beta^{r}>\beta^{u}$.

\section{References}

Atkinson, Anthony B., and Micklewright, John. "Unemployment Compensation and Labor Market Transitions: A Critical Review." J. Econ. Literalure 29 (December 1991): 1679-1727.

Backus, David K.; Kehoe, Patrick J.; and Kydland, Finn E. "International Real Business Cycles." J.P.E. 100 (August 1992): 745-75.

Baxter, Marianne, and Crucini, Mario. "Business Cycles and the Asset Structure of Foreign Trade." Internat. Econ. Rev. 36 (November 1995): $821-54$.

Baxter, Marianne, and Jermann, Urban J. "Household Production and the Excess Sensitivity of Consumption to Current Income." Working paper. Charlottesville: Univ. Virginia, May 1994.

Baxter, Marianne; Jermann, Urban J.; and King, Robert G. "Nontraded Goods, Nontraded Factors, and International Nondiversification." Worl:ing paper. Charlottesville: Univ. Virginia, June 1994.

Burdett, Kenneth, and Wright, Randall. "Unemployment Insurance and Short-Time Compensation: The Effects on Layoffs, Hours per Worker, and Wages." J.P.E. 97 (December 1989): 1479-96.

Canova, Fabio, and Ravn, Morten O. "International Consumption Risk Sharing." Working Paper no. 93-43. Providence, R.I.: Brown Univ., Dept. Econ., 1993.

Clarida, Richard H. "International Lending and Borrowing in a Stochastic, Stationary Equilibrium." Inlernat. Econ. Rev. 31 (August 1990): 543-58.

Cochrane, John H. "A Simple Test of Consumption Insurance." J.P.E. 99 (October 1991): 957-76. 
Conze, Antoine; Lasry, Jean-Michel; and Scheinkman, José A. "Borrowing Constraints and International Comovements." Hitolsubashi J. Econ. 34 (suppl.; December 1993): 23-47.

Cumby, Robert E., and Huizinga, John. "Testing the Autocorrelation Structure of Disturbances in Ordinary Least Squares and Instrumental Variables Regressions." Econometrica 60 (January 1992): 185-95.

Cuoco, Domenico, and Cvitanić, Jaksa. "Optimal Consumption Choices for a 'Large' Investor." Working paper. Philadelphia: Univ. Pennsylvania, January 1995.

Devereux, M. B.; Gregory, Allan W.; and Smith, Gregor W. "Realistic CrossCountry Consumption Correlations in a Two-Country, Equilibrium, Business Cycle Model." J. Internat. Money and Finance 11 (February 1992): 3-16.

Heaton, John, and Lucas, Deborah J. "Evaluating the Effects of Incomplete Markets on Risk Sharing and Asset Pricing." Working Paper no. 3491-92EFA. Cambridge: Massachusetts Inst. Tech., Sloan School Management, November 1992.

- "The Importance of Investor Heterogeneity and Financial Market Imperfections for the Behavior of Asset Prices." Carnegie-Rochester Conf. Ser. Public Policy 42 (June 1995): 1-32.

Ingersoll, Jonathan E., Jr. "Portfolio Separation Theorems." In Theory of Financial Decision Making. Totowa, Md.: Rowman and Littlefield, 1987.

Kravis, Irving B.; Heston, Alan; and Summers, Robert. World Product and Income: International Comparisons of Real Gross Product. Baltimore: Johns Hopkins Univ. Press (for World Bank), 1982.

Leme, Paulo. "Integration of International Capital Markets." Working paper. Chicago: Univ. Chicago, 1984.

Lewis, Karen. "Puzzles in International Finance." In Handbook of International Economics, edited by Gene Grossman and Kenneth Rogoff. Amsterdam: North-Holland, 1995.

Mace, Barbara J. "Full Insurance in the Presence of Aggregate Uncertainty." J.P.E. 99 (October 1991): 928-56.

Obstfeld, Maurice. "How Integrated Are World Capital Markets? Some New Tests." In Debt, Stabilization, and Development: Essays in Memory of Carlos Diaz-Alejandro, edited by Guillermo Calvo, Ronald Findlay, and Jorge de Macedo. Oxford: Blackwell, 1989.

- "Are Industrial-Country Consumption Risks Globally Diversified?" In Capital Mobility: The Impact on Consumption, Investment and Growth, edited by Leonardo Leiderman and Assaf Razin. Cambridge: Cambridge Univ. Press, 1994. (a)

- "Risk-Taking, Global Diversification, and Growth." A.E.R. 84 (December 1994): 1310-29. (b)

Scheinkman, José A. "General Equilibrium Models of Economic Fluctuations: A Survey of Theory." Working paper. Chicago: Univ. Chicago, 1984.

Stockman, Alan C., and Tesar, Linda L. "Tastes and Technology in a TwoCountry Model of the Business Cycle: Explaining International Comovements." A.E.R. 85 (March 1995): 168-85.

Stulz, René M. "A Model of International Asset Pricing." J. Financial Econ. 9 (December 1981): 383-406.

(Dec "An Equilibrium Model of Exchange Rate Determination and Asset Pricing with Nontraded Goods and Imperfect Information." J.P.E. 95 (October 1987): 1024-40. 
Summers, Robert, and Heston, Alan. "The Penn World Table (Mark 5): An Expanded Set of International Comparisons, 1950-1988." Q.J.E. 106 (May 1991): 327-68.

Telmer, Chris I. "Asset-Pricing Puzzles and Incomplete Markets." J. Finance 48 (December 1993): 1803-32.

Tesar, Linda L. "International Risk Sharing and Non-traded Goods." J. Internat. Econ. 35 (August 1993): 69-89.

Zeldes, Stephen P. "Consumption and Liquidity Constraints: An Empirical Investigation." J.P.E. 97 (April 1989): 305-46. 